\title{
Developing rural tourism in the context of sustainable bioeconomy - a Romanian perspective
}

\author{
Shahrazad HADAD \\ The Bucharest University of Economic Studies, Romania \\ shahrazad.hadad@fabiz.ase.ro
}

PICBE | 537

\begin{abstract}
Due to the massive urbanization during the second half of the 20th century, rural areas have undergone major structural changes defined by the migration of villagers to cities (implicitly the depopulation of villages), the introduction of new techniques and technologies for working the land and infrastructure developments. In order to call public attention upon these problems and in the attempt to rehabilitate rural areas, more intensive exploitation of tourism resources has taken place. Tourist resources are the elements referring to the social, cultural, historical, human and natural specifics of a country. In rural tourism, travelers take part in the activities, lifestyle and traditions of rural communities, and in this manner they benefit from an entirely personalized experience. They usually rent rural accommodation, which they can combine with rural activities and attractions (recreational and fun). Rural tourism is defined as all rural tourism activities, primarily agrotourism boarding houses and farms, but also small restaurants and hotels or other accommodation. However, there are countries that classify any activity undertaken outside the city as rural tourism. Research in the field of rural tourism development favors the creation of so-called integrated rural tourism (at both the theoretical and practical level) for the exploitation of underdeveloped regions, creating strong links between the social, cultural, economic and environmental resources. The aim of the present study is to evaluate the level of rural tourism in Romania by means of econometric methods and establish means of aligning the Romanian rural tourism product to international standards. One of the main conclusions the present study draws that is tourism is an important economic segment of sustainable development and is also a key component in the formation of the country image at regional and international level.
\end{abstract}

Keywords: rural tourim, sustainability, bioeconomy, sustainable bioeconomy, green tourism.

\section{Introduction}

Due to its geographical position and its rich history, Romania has a tremendous touristic potential especially in the area of rural tourism. Its beautiful mountains and its extensive beaches which open towards the Black Sea, as well as the cultural heritage of its numerous villages which has been preserved by local communities have transformed Romania into the preferred destination for rural tourism in Europe (Avram, 2017). In recent years, the interest towards touristic attractions from rural areas in Romania has received a consistent boost from the coverage in international press concerning the activities performed by the Prince of Wales in Covasna where he bought and refurbished an old Romanian guesthouse and opened it to the tourists. Besides the significant support offered by Prince Charles for the development of rural tourism in Transylvania, Romania also benefited from the international exposure generated by the fact that numerous TV series such as Top Gear or Bear Grylls chose to film segments in rural Romanian areas. In addition, the documentary series Wild Carpathia created by the British journalist Charlie Otley helped reinforce the idea that the natural patrimony from Transylvania, Bucovina and Moldavia deserve international attention. As a result, Romania has become an attractive destination for international tourists looking for authentic rural experiences and for locations that are less popular and less populated by other tourists. 


\section{Literature Review}

Due to the massive urbanization of the second half of the twentieth century, which is still ongoing, the rural areas have undergone major structural changes defined by the migration of the villagers to the cities (implicitly the depopulation of villages), the introduction of new techniques and technologies for working the of land and PICBE | 538 infrastructure development. In order to draw attention to these problems and in the attempt to rehabilitate the rural areas, it was proceeded to the more intensive exploitation of the tourist resources (the tourist resources are the elements that refer to the social, cultural, historical, human and natural characteristics of a country). With the scale of the Internet of Things movement and the new context of digitalization, consumers have become much more informed and demanding compared to the period before the digital boom. Thus, there has been a paradigm shift from the simple purchase of products or services to the acquisition of the most authentic and personalized experiences (Roberts et al., 2017).

In rural tourism, travelers take part in the activities, lifestyle and traditions of rural communities and in this way benefit from a completely personalized experience (Dorobantu et al., 2012). They usually rent rural accommodation that they can combine with activities and attractions in the countryside (recreational and entertainment). Rural tourism is defined as being represented by all the tourism activities carried out in the rural area, firstly the pensions and agro-tourism farms, but also the small restaurants and hotels or other forms of accommodation (Roberts et al., 2017). However, there are countries that classify as any rural activity any activity undertaken outside the city.

At the level of Romania, in 2016 the value of rural tourism reached 290 million euros, accounting for $18.46 \%$ of the country's total; in relation to the income and expenses generated by this activity, there is a positive difference of the income towards the expenses (Stoican and Camarda, 2018). Thus, tourism is an important segment of sustainable development of the economy, also representing a key component in the formation of the country image at regional and international level (Dorobantu and Nistoreanu, 2012). In order to increase the competitiveness of the foreign tourism market, the Romanian tourism product must be aligned with international standards (Roman, 2009). Moreover, rural tourism can be used as a tool to differentiate products in stagnant areas (Kantar and Svržnjak, 2017).

The researches carried out in the field of rural tourism development militate for the creation of the so-called integrated rural tourism (both at the theoretical and practical level) for the exploitation of the underdeveloped regions creating strong links (networks) between their social, cultural, economic and environmental resources (Saxena et al., 2007). The notion also aims to open up practical ways of thinking about improving the links between tourism and resources, activities, products and local and regional communities in light of the dynamic trends in tourism demand. For example, the newest concern at European Union level, within the European Agricultural Fund for Rural Development (2017), is to support the rural tourism infrastructure through programs in which entrepreneurs from rural businesses, farmers, landowners, charities and organizations public can apply for grants of up to 40,000 euros for projects that contribute to improving the rural tourism offer by providing new goods and services and viable infrastructure 
However, Romania still has a long way to go before reaching its true potential in the area of rural tourism. This is reflected in the poor contribution of the entire tourism sector to Romanian GDP was around 1.4\% in 2018, which is still below the average global level of 3\% ("Turismul romanesc", 2018) and the fact that a large proportion of tourists still prefer urban areas (approximately 70\% of incoming tourists) (Anghelache, Anghel \& Samson, 2018). According to the president of ANTREC (The National Association for Rural Tourism in Romania), the main barriers to growth are related to the poor collaboration between rural guesthouses and tourism agencies because these companies prefer to work with entities that have a larger number of available places and because the timing of the local festivals is not fully establish and they cannot effectively advertise these touristic opportunities (Matei, 2018). In addition, rural guesthouses suffer from a lack of trained workforce and because their offers are not promoted through specialized websites due to the fact that the employees lack the necessary digital skills (Matei, 2018).

In spite of these setbacks, the most recent statistics show a growth in the number of agritourist guesthouses and an increase in the number of guests and the number of nights spent in Romania, which is a sign that the rural tourism sector is moving towards the achievement of its true potential (Anghelache et al., 2018). In fact, the reality might be better than reflected by national statistics, because these record data on the number of economic entities and tourists based on a classification which makes it difficult to truly estimate the size of rural tourism in Romania: seaside resorts, mountain resorts, balneal resorts, Danube Delta and large cities. This is also true of statistics at the European Union level which do not measure specifically the evolution of rural tourism, instead focusing on other means of classification (Avram, 2017).

In light of this, the present paper aims to explore the development of rural tourism based on the latest statistics provided by the Romanian Ministry of Tourism related to the number and capacity of all accredited tourism lodgings in the country. Based on this data, the paper will establish the level of development of rural tourism for each county and then to explore the influence of the factors most likely to have impacted this level of development (e.g., size of the county, number of residents in urban and rural areas, county GDP, the level of the average net salary in the county etc.).

\section{Factors contributing to the development of rural tourism}

With regards to economic factors, two aspects seem to us to be of greater importance, namely: personal or family income and the fees charged for tourism and agrotourism services. It is relatively easy to imagine the intensification of the tourist circulation as the incomes increase and reach to exceed that critical level until the financial means available in a household are totally dominated by the need to satisfy the basic consumption requirements, such as food, clothing long-term industrial products, etc. Regarding the tariffs, it is clear that they can have an inhibiting effect if they will increase or favor the tourist flows if they decrease (Sumantra and Yuesti, 2018).

Psychological factors are the most difficult to estimate because they express very different individualized preferences. In this case, we are confronted with that tourist motivation, that is, the one that causes the man to move from his place of residence to another locality or geographical area. 
The demographic factors can cause a complex of positive effects on the main tourist currents, as a result of the population growth, of the changes made in the age structure and the professional structure, to increase the urban population. From now on, the so-called "civilization of free time" has started to take on unexpected dimensions, raising a lot of economic and social aspects. A phenomenon that is becoming increasingly important in the evolution of tourism is the entry into the tourist circuits of new age groups - young and old.

On the other hand, the natural factors hold an extremely important place in the choice of routes, stopping places and length of stay. In this sense, we cannot ignore the fact that we prefer the coast or the mountain, we prefer the sunny area, or we will practice winter sports.

Additionally, conjectural factors usually have a temporary effect on the tourist expansion to certain geographical areas or regions. Among these factors we mention the inflationary phenomenon, the economic crises, the proportions of unemployment, and changes in the currency system, the energy crisis (Gabriel, 2013).

Furthermore, from the combined analysis of all these factors and from following the evolution of the rural tourism so far, especially in the mountain areas, there are some tendencies characteristic of the tourist flows, namely:

1. the trend of continuous upward development, which seems to be long-term;

2. the tendency of continuous diversification of the tourist demand as a consequence of the motivation of the tourists, of the modifications made in the age categories and of the transformation of the tourism, sometimes, in a mass phenomenon;

3. recording significant differences in the tourist circulation from one area to another;

4. the tendency of the increase of the expenses for the tourist services in the total of the family budgets, as the incomes of the population increase, the gross domestic product per inhabitant and the level of economic development;

5. increasing the duration and distance for which a trip is made, as a result of the development of transport and infrastructure.

\section{Methodology}

The present paper investigates the concept of rural tourism in general and in Romania, first by means of literature review that embodies half of the mixed method research methodology: the qualitative approach. Whereas in the second part of the paper, the research shifts to quantitative approach and investigates the factors influencing rural tourism in Romania and its evolution by resorting to stepwise linear regression analysis. The data used in this research is mainly secondary coming from statistics developed by Romanian entities responsible with tourism.

\section{Research results and discussion}

Since 2000, rural tourism, measured through the evolution of the number and guests received by agritourist guesthouses in Romania, has been in a constant state of development. As shown in table 1, in 2000, Romania had only 400 agritourist guesthouses which housed only 28200 tourists annually. However, by the end of 2017, Romania had 
2556 agritourist guesthouses which housed more than 1 million Romanian and foreign tourists, which signals a 6-fold increase in the number of structures and capacity.

Table 1. The evolution of the number of agritourist guesthouses in Romania

\begin{tabular}{|l|l|l|l|l|l|l|l|l|}
\hline $\mathbf{2 0 0 0}$ & $\mathbf{2 0 0 1}$ & $\mathbf{2 0 0 2}$ & $\mathbf{2 0 0 3}$ & $\mathbf{2 0 0 4}$ & $\mathbf{2 0 0 5}$ & $\mathbf{2 0 0 6}$ & $\mathbf{2 0 0 7}$ & $\mathbf{2 0 0 8}$ \\
\hline 400 & 536 & 682 & 781 & 892 & 956 & 1259 & 1292 & 1348 \\
\hline $\mathbf{2 0 0 9}$ & $\mathbf{2 0 1 0}$ & $\mathbf{2 0 1 1}$ & $\mathbf{2 0 1 2}$ & $\mathbf{2 0 1 3}$ & $\mathbf{2 0 1 4}$ & $\mathbf{2 0 1 5}$ & $\mathbf{2 0 1 6}$ & $\mathbf{2 0 1 7}$ \\
\hline 1412 & 1210 & 1569 & 1569 & 1598 & 1724 & 1918 & 2028 & 2556 \\
\hline
\end{tabular}

Source: National Institute of Statistics.

Based on the analysis of the data in SPSS, the following linear regression line was obtained:

Number of agritourist guesthouses $=-198588.533+99.525^{*}$ year $(\mathrm{R}$ square $=$ 0.927 , sig. $=0.000$ )

The same positive evolution has also been registered at the level of the capacity of agritourist guesthouses in Romania, which has grown 14 times in the period between 2000 and 2017.

Table 2. The evolution of the capacity of agritourist guesthouses in Romania (places-days thousands)

\begin{tabular}{|l|l|l|l|l|l|l|l|l|}
\hline $\mathbf{2 0 0 0}$ & $\mathbf{2 0 0 1}$ & $\mathbf{2 0 0 2}$ & $\mathbf{2 0 0 3}$ & $\mathbf{2 0 0 4}$ & $\mathbf{2 0 0 5}$ & $\mathbf{2 0 0 6}$ & $\mathbf{2 0 0 7}$ & $\mathbf{2 0 0 8}$ \\
\hline 805.6 & 1105.7 & 1270.5 & 1614.5 & 2132 & 2528.3 & 3188.4 & 3625.6 & 4038.9 \\
\hline $\mathbf{2 0 0 9}$ & $\mathbf{2 0 1 0}$ & $\mathbf{2 0 1 1}$ & $\mathbf{2 0 1 2}$ & $\mathbf{2 0 1 3}$ & $\mathbf{2 0 1 4}$ & $\mathbf{2 0 1 5}$ & $\mathbf{2 0 1 6}$ & $\mathbf{2 0 1 7}$ \\
\hline 4735.5 & 4891.9 & 5378.4 & 6864.9 & 7932.6 & 8546.2 & 9079.9 & 10336.7 & 11787.8 \\
\hline
\end{tabular}

Source: National Institute of Statistics

Based on the analysis of the data found in table 2 in SPSS, the following linear regression line was obtained:

Capacity of agritourist guesthouses $=-1240610.059+620.166^{*}$ year $(\mathrm{R}$ square $=$ 0.957, sig. $=0.000$ )

Similarly, the number of tourists housed by agritourist guesthouses in Romania has increased from a mere 28200 in 2000 to more than 1 million in 2017.

Table 3. The evolution of the number of tourists in agritourist guesthouses in Romania (thousands)

\begin{tabular}{|l|l|l|l|l|l|l|l|l|}
\hline $\mathbf{2 0 0 0}$ & $\mathbf{2 0 0 1}$ & $\mathbf{2 0 0 2}$ & $\mathbf{2 0 0 3}$ & $\mathbf{2 0 0 4}$ & $\mathbf{2 0 0 5}$ & $\mathbf{2 0 0 6}$ & $\mathbf{2 0 0 7}$ & $\mathbf{2 0 0 8}$ \\
\hline 28.2 & 41.7 & 64.8 & 89.4 & 149.1 & 170.2 & 217 & 288.5 & 357.6 \\
\hline $\mathbf{2 0 0 9}$ & $\mathbf{2 0 1 0}$ & $\mathbf{2 0 1 1}$ & $\mathbf{2 0 1 2}$ & $\mathbf{2 0 1 3}$ & $\mathbf{2 0 1 4}$ & $\mathbf{2 0 1 5}$ & $\mathbf{2 0 1 6}$ & $\mathbf{2 0 1 7}$ \\
\hline 325.7 & 289.9 & 360.7 & 447.1 & 501.7 & 568.4 & 672.7 & 813.4 & 1004.4 \\
\hline
\end{tabular}

Source: National Institute of Statistics

Based on the analysis of the data found in table 3 in SPSS, the following linear regression line was obtained:

Number of tourists $=-97365.234+48.653^{*}$ year $($ R square $=0.901$, sig. $=0.000)$

According to the Ministry of Tourism statistics for 2019, the most frequent type of accommodation in rural areas is represented by guesthouses (58.54 percent of the total number of touristic lodgings), followed by rooms to let (17.49 percent of the total number of touristic lodgings) and hotels (4.29 percent of the total number of touristic lodgings). 
Table 4. Rural touristic accommodations by county and type

\begin{tabular}{|c|c|c|c|c|c|c|c|c|c|c|c|c|c|}
\hline County & Apartment & Bungalow & Cottage & $\begin{array}{c}\text { Rooms to } \\
\text { let }\end{array}$ & Camping & Hostel & Hotel & Motel & $\begin{array}{c}\text { Water } \\
\text { lodgings }\end{array}$ & Guesthouse & $\begin{array}{c}\text { Tourist } \\
\text { relay }\end{array}$ & $\begin{array}{l}\text { Tourist } \\
\text { village }\end{array}$ & Villa \\
\hline Arad & 0 & 9 & 5 & 8 & 4 & 2 & 6 & 3 & 0 & 38 & 1 & 1 & 6 \\
\hline Argeș & 1 & 0 & 16 & 64 & 6 & 5 & 14 & 4 & 0 & 173 & 1 & 0 & 11 \\
\hline Bacău & 0 & 1 & 1 & 21 & 5 & 1 & 2 & 7 & 0 & 47 & 0 & 0 & 0 \\
\hline Bihor & 7 & 1 & 5 & 75 & 7 & 2 & 26 & 6 & 0 & 175 & 0 & 0 & 24 \\
\hline $\begin{array}{l}\text { Bistrița- } \\
\text { Năsăud }\end{array}$ & 0 & 1 & 7 & 6 & 2 & 1 & 5 & 0 & 0 & 81 & 0 & 0 & 0 \\
\hline Botoșani & 1 & 2 & 0 & 2 & 0 & 1 & 0 & 1 & 0 & 12 & 0 & 0 & 0 \\
\hline Brăila & 0 & 0 & 0 & 2 & 4 & 0 & 7 & 1 & 1 & 3 & 1 & 0 & 2 \\
\hline Brașov & 9 & 7 & 14 & 86 & 3 & 3 & 19 & 3 & 0 & 467 & 0 & 1 & 33 \\
\hline Buzău & 1 & 1 & 0 & 23 & 2 & 4 & 9 & 3 & 0 & 66 & 0 & 0 & 6 \\
\hline Călarași & 1 & 0 & 0 & 4 & 3 & 0 & 0 & 1 & 0 & 5 & 1 & 0 & 0 \\
\hline Caraș-Severin & 2 & 3 & 20 & 10 & 4 & 4 & 3 & 0 & 0 & 88 & 2 & 0 & 3 \\
\hline Cluj & 5 & 3 & 4 & 46 & 3 & 8 & 10 & 4 & 0 & 188 & 1 & 1 & 5 \\
\hline Constanța & 15 & 24 & 3 & 272 & 13 & 50 & 31 & 2 & 1 & 50 & 1 & 0 & 81 \\
\hline Covasna & 0 & 0 & 1 & 29 & 6 & 3 & 1 & 5 & 0 & 66 & 1 & 0 & 6 \\
\hline Dâmbovița & 0 & 1 & 5 & 5 & 1 & 7 & 8 & 2 & 0 & 42 & 0 & 0 & 2 \\
\hline Dolj & 0 & 1 & 2 & 1 & 0 & 1 & 5 & 2 & 0 & 19 & 1 & 0 & 0 \\
\hline Galați & 0 & 1 & 0 & 0 & 0 & 0 & 1 & 1 & 0 & 5 & 1 & 0 & 1 \\
\hline Giurgiu & 3 & 1 & 1 & 6 & 1 & 1 & 3 & 3 & 0 & 8 & 0 & 0 & 0 \\
\hline Gorj & 0 & 1 & 7 & 7 & 0 & 5 & 2 & 1 & 0 & 111 & 2 & 0 & 5 \\
\hline Harghita & 5 & 0 & 18 & 27 & 10 & 5 & 4 & 1 & 0 & 256 & 0 & 0 & 0 \\
\hline Hunedoara & 1 & 0 & 10 & 22 & 2 & 1 & 8 & 4 & 0 & 71 & 0 & 0 & 8 \\
\hline Ialomița & 0 & 0 & 1 & 2 & 0 & 0 & 0 & 1 & 0 & 0 & 0 & 0 & 0 \\
\hline Iași & 1 & 1 & 1 & 5 & 2 & 1 & 6 & 1 & 0 & 33 & 2 & 0 & 4 \\
\hline Ilfov & 0 & 2 & 0 & 6 & 2 & 4 & 10 & 2 & 0 & 17 & 1 & 0 & 5 \\
\hline Maramureș & 4 & 0 & 4 & 72 & 9 & 1 & 7 & 1 & 0 & 220 & 3 & 0 & 4 \\
\hline Mehedinți & 1 & 0 & 1 & 12 & 0 & 0 & 2 & 1 & 0 & 53 & 0 & 0 & 4 \\
\hline Mureș & 4 & 0 & 1 & 8 & 2 & 2 & 6 & 11 & 0 & 76 & 1 & 1 & 4 \\
\hline Neamț & 2 & 7 & 6 & 33 & 9 & 9 & 11 & 4 & 0 & 184 & 3 & 0 & 7 \\
\hline Olt & 0 & 0 & 1 & 0 & 0 & 0 & 0 & 0 & 0 & 7 & 0 & 0 & 0 \\
\hline Prahova & 4 & 1 & 5 & 16 & 4 & 3 & 9 & 10 & 0 & 70 & 0 & 0 & 8 \\
\hline Sălaj & 1 & 2 & 0 & 5 & 3 & 1 & 3 & 0 & 0 & 47 & 0 & 0 & 0 \\
\hline Satu Mare & 0 & 0 & 0 & 2 & 0 & 0 & 4 & 2 & 0 & 23 & 1 & 0 & 0 \\
\hline Sibiu & 7 & 1 & 18 & 26 & 5 & 3 & 6 & 5 & 0 & 144 & 0 & 0 & 16 \\
\hline Suceava & 8 & 2 & 13 & 76 & 10 & 7 & 6 & 4 & 0 & 314 & 2 & 1 & 6 \\
\hline Teleorman & 0 & 0 & 1 & 0 & 0 & 0 & 0 & 0 & 0 & 6 & 0 & 0 & 0 \\
\hline Timiș & 0 & 1 & 10 & 4 & 1 & 7 & 11 & 1 & 0 & 52 & 1 & 0 & 3 \\
\hline Tulcea & 2 & 32 & 1 & 52 & 13 & 0 & 9 & 0 & 17 & 154 & 4 & 3 & 79 \\
\hline Vâlcea & 2 & 5 & 4 & 9 & 2 & 1 & 4 & 5 & 0 & 101 & 1 & 0 & 11 \\
\hline Vaslui & 0 & 0 & 0 & 2 & 0 & 0 & 0 & 2 & 0 & 13 & 0 & 0 & 0 \\
\hline Vrancea & 1 & 1 & 1 & 9 & 2 & 0 & 1 & 5 & 0 & 46 & 1 & 0 & 3 \\
\hline Total & 88 & 112 & 187 & 1055 & 140 & 143 & 259 & 109 & 19 & 3531 & 33 & 8 & 347 \\
\hline
\end{tabular}


Table 4 can be very easily considered in conjunction with Figures 1 and 2, that emphasises the intensity of rural tourism based on the number of available places. Most of the counties of the contry have fewer than 1000 places available for accommodating tourist, whereas, for example, counties such as Bihor, Brasov, Tulcea and Suceava ensure between 6001- 20000.

PICBE $\mid 543$

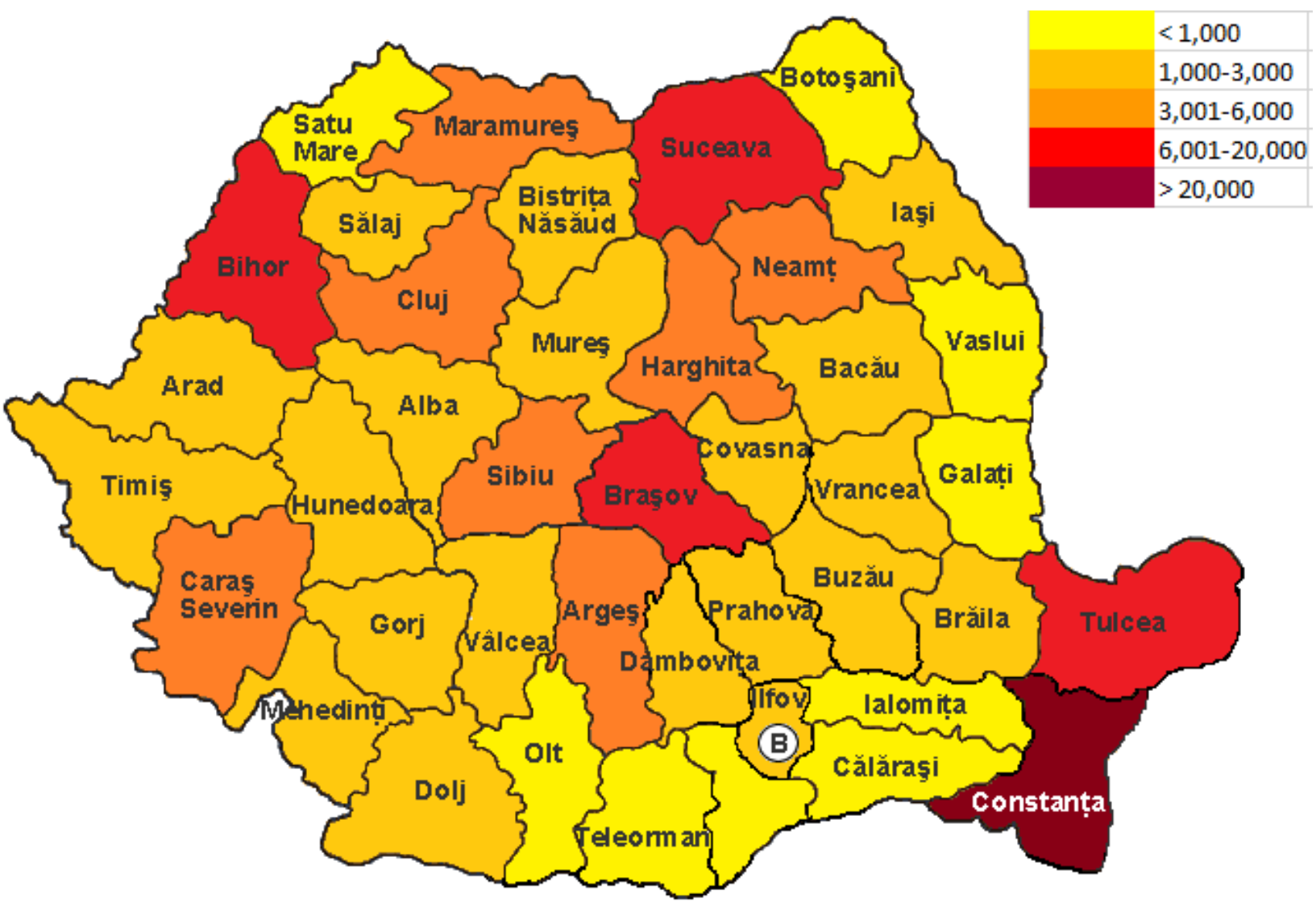

Figure 1. Intensity of rural tourism based on number of available places

Source: Author's own design based on statistics from the Ministry of Tourism.

This map depicts some of the European funds for the development of rural tourism. It translates Tulcea, and the others have attracted funds for infrastructure development. This is factor that could explain why certain counties are better at this chapter as compared to the others. Besides, there are also some environmental factors - Tulcea has the Danube Delta, Brasov has a large array of the Carpathian mountains making it a clear attraction for hickers and mountain passionates. Bistrita Nasaud (cultural factors prevail), Cluj, Suceava (part of Bucovina, traditions, arts and crafts prevail) and Brasov score highest in terms of total number of actions per country and moreover they display a predominant recreational infrastructure and touristic accommodation. 


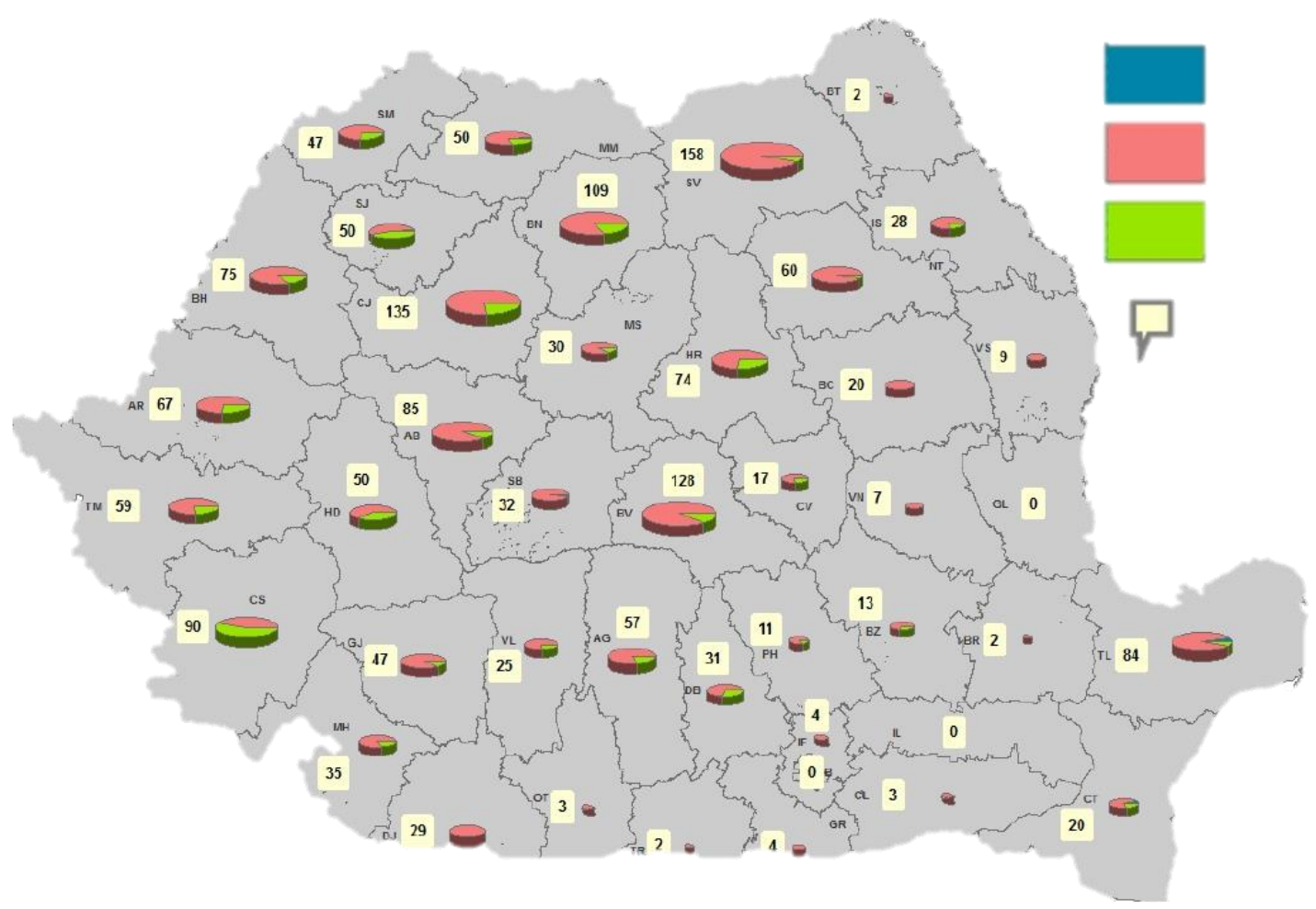

PICBE | 544

Figure 2. County distribution by number of actions

Source: http://media.hotnews.ro/media_server1/image-2015-10-28-20538532-0-hartaafacerilor-turism-fonduri.jpg

Blue - Development/ Promotion of rural tourism services; Pink - Recreational infrastructure and touristic accommodation; Green - Small scale infrastructure (tourist information points); Item box - Total number of actions per county

The research took into consideration several factors - the surface of the county, number of inhaboitants in the rural/urban area, PIB per county 2018 and net salary 2018; the number of inhabitants in the rural areas and the salary were not correlted with any of the other variables thefore they were discaarded from the analysis. The remainder of the variables were used in order to build the regression.

For the number of structures in rural areas, the results of the stepwise linear regression revealed that the best predictors are the surface area of the county and the GDP per capita at the level of the county:

Number of structures $=-277.739+0.038 *$ surface $+25.189 *$ GDP per capita

Table 5. Model Summary

\begin{tabular}{|c|c|c|c|c|}
\hline Model & $\mathrm{R}$ & R Square & Adjusted R Square & Std. Error of the Estimate \\
\hline 1 & $.439^{\mathrm{a}}$ & .193 & .172 & 141.738 \\
2 & $.566^{\mathrm{b}}$ & .321 & .284 & 131.772 \\
\hline
\end{tabular}

a. Predictors: (Constant), Surface; b. Predictors: (Constant), Surface, GDP/inhabitant euro

Table 6. ANOVAa

\begin{tabular}{|c|c|c|c|c|c|c|}
\hline \multicolumn{2}{|c|}{ Model } & Sum of Squares & $\mathrm{df}$ & Mean Square & $\mathrm{F}$ & Sig. \\
\hline 1 & $\begin{array}{c}\text { Regression } \\
\text { Residual } \\
\text { Total }\end{array}$ & $\begin{array}{l}182291.219 \\
763408.556 \\
945699.775\end{array}$ & $\begin{array}{c}1 \\
38 \\
39\end{array}$ & $\begin{array}{c}182291.219 \\
20089.699\end{array}$ & 9.074 & $.005^{b}$ \\
\hline 2 & $\begin{array}{c}\text { Regression } \\
\text { Residual } \\
\text { Total }\end{array}$ & $\begin{array}{l}303239.882 \\
642459.893 \\
945699.775\end{array}$ & $\begin{array}{c}2 \\
37 \\
39\end{array}$ & $\begin{array}{c}151619.941 \\
17363.781\end{array}$ & 8.732 & $.001^{\mathrm{c}}$ \\
\hline
\end{tabular}

a. Dependent Variable: Number of structures; b. Predictors: (Constant), Surface; c. Predictors: (Constant), Surface, GDP/inhabitant euro 
Table 7. Coefficients ${ }^{\mathrm{a}}$

\begin{tabular}{|c|c|c|c|c|c|c|}
\hline \multirow{2}{*}{\multicolumn{2}{|c|}{ Model }} & \multicolumn{2}{|c|}{ Unstandardized Coefficients } & \multirow{2}{*}{$\begin{array}{c}\text { Standardized } \\
\text { Coefficients }\end{array}$} & \multirow[b]{2}{*}{$t$} & \multirow[b]{2}{*}{ Sig. } \\
\hline & & $\mathrm{B}$ & Std. Error & & & \\
\hline \multirow[t]{2}{*}{1} & (Constant) & -105.669 & 87.921 & & -1.202 & .237 \\
\hline & Surface & .044 & .015 & .439 & 3.012 & .005 \\
\hline \multirow[t]{3}{*}{2} & (Constant) & -277.739 & 104.555 & & -2.656 & .012 \\
\hline & Surface & .038 & .014 & .375 & 2.725 & .010 \\
\hline & GDP/inhabitant euro & 25.189 & 9.544 & .363 & 2.639 & .012 \\
\hline
\end{tabular}

a. Dependent Variable: Number of structures

Table 8. Excluded Variables ${ }^{a}$

\begin{tabular}{|ll|r|r|r|r|r|}
\hline & & & & & & \multicolumn{2}{c|}{$\begin{array}{c}\text { Collinearity } \\
\text { Statistics }\end{array}$} \\
\cline { 6 - 8 } Model & & & & \multicolumn{2}{c|}{$\begin{array}{c}\text { Partial } \\
\text { Correlation }\end{array}$} & \multicolumn{1}{c|}{ Tolerance } \\
\hline 1 & Locuitori urban & Seta In & \multicolumn{1}{c|}{$\mathrm{t}$} & \multicolumn{1}{c|}{ Sig. } & .288 & .802 \\
& PIB judetean 2018 mil euro & $.288^{\mathrm{b}}$ & 1.826 & .076 & .328 & .923 \\
& GDP/inhabitant euro & $.306^{\mathrm{b}}$ & 2.109 & .042 & .398 & .969 \\
\hline 2 & Locuitori urban & $.363^{\mathrm{b}}$ & 2.639 & .012 & .083 & .546 \\
& PIB judetean 2018 mil euro & $.092^{\mathrm{c}}$ & .499 & .620 & .015 & .268 \\
\hline
\end{tabular}

a. Dependent Variable: Number of structures

b. Predictors in the Model: (Constant), Surface

c. Predictors in the Model: (Constant), Surface, GDP/inhabitant euro

Similar results were obtained for the number of places in touristic accommodations found in rural areas. The results of the stepwise linear regression revealed the best predictors to be also the surface area of the county and the county's GDP per capita:

Number of places $=-8402.242+0.779 *$ surface $+859.681 *$ GDP per capita

Table 9. Model Summary

\begin{tabular}{|l|r|r|r|r|}
\hline Model & $\mathrm{R}$ & \multicolumn{1}{|c|}{ R Square } & \multicolumn{1}{c|}{ Adjusted R Square } & Std. Error of the Estimate \\
\hline 1 & $.519 \mathrm{a}$ & .269 & .250 & 3575.339 \\
2 & $.593^{\mathrm{b}}$ & .352 & .317 & 3412.344 \\
\hline
\end{tabular}

a. Predictors: (Constant), GDP/inhabitant euro

b. Predictors: (Constant), GDP/inhabitant euro, Surface

Table10. ANOVA ${ }^{\mathrm{a} .}$

\begin{tabular}{|ll|r|r|r|r|r|}
\hline Model & Sum of Squares & df & Mean Square & \multicolumn{1}{|c|}{ F } & Sig. \\
\hline 1 & Regression & 179066818.335 & 1 & 179066818.335 & 14.008 & $.001^{\mathrm{b}}$ \\
& Residual & 485755869.440 & 38 & 12783049.196 & & \\
& Total & 664822687.775 & 39 & & & \\
\hline 2 & Regression & 233991250.747 & 2 & 116995625.373 & 10.048 & $.000^{\mathrm{c}}$ \\
& Residual & 430831437.028 & 37 & 11644092.893 & & \\
& Total & 664822687.775 & 39 & & & \\
\end{tabular}

a. Dependent Variable: Number of places

b. Predictors: (Constant), GDP/inhabitant euro

c. Predictors: (Constant), GDP/inhabitant euro, Surface 
Table 11. Coefficients ${ }^{a}$

\begin{tabular}{|c|c|c|c|c|c|c|}
\hline \multirow[b]{2}{*}{ Mod } & & \multicolumn{2}{|c|}{ Unstandardized Coefficients } & $\begin{array}{c}\text { Standardized } \\
\text { Coefficients }\end{array}$ & \multirow[b]{2}{*}{$\mathrm{t}$} & \multirow[b]{2}{*}{ Sig. } \\
\hline & & $\mathrm{B}$ & Std. Error & Beta & & \\
\hline \multirow[t]{2}{*}{1} & (Constant) & -4671.254 & 2192.737 & & -2.130 & .040 \\
\hline & GDP/inhabitant euro & 954.100 & 254.920 & .519 & 3.743 & .001 \\
\hline \multirow[t]{3}{*}{2} & (Constant) & -8402.242 & 2707.550 & & -3.103 & .004 \\
\hline & GDP/inhabitant euro & 859.681 & 247.152 & .468 & 3.478 & .001 \\
\hline & Surface & .779 & .359 & .292 & 2.172 & .036 \\
\hline
\end{tabular}

PICBE $\mid 546$

a. Dependent Variable: Number of places

Table 12. Excluded Variables ${ }^{a}$

\begin{tabular}{|ll|r|r|r|r|r|}
\hline & & & & & & \multicolumn{2}{c|}{$\begin{array}{c}\text { Collinearity } \\
\text { Statistics }\end{array}$} \\
\cline { 6 - 8 } Model & & & & \multicolumn{1}{c|}{$\begin{array}{c}\text { Partial } \\
\text { Correlation }\end{array}$} & \multicolumn{1}{c|}{ Tolerance } \\
\hline 1 & Surface & Beta In & \multicolumn{1}{c|}{$\mathrm{t}$} & .336 & .969 \\
& Urban inhabitants & $.292^{\mathrm{b}}$ & 2.172 & .036 & .270 & .668 \\
& County GDP 2018 mil euro & $.282^{\mathrm{b}}$ & 1.703 & .097 & .126 & .285 \\
\hline 2 & Urban inhabitants & $.201^{\mathrm{b}}$ & .770 & .446 & .148 & .546 \\
& County GDP 2018 mil euro & $.161^{\mathrm{c}}$ & .898 & .375 & .047 & .268 \\
\hline
\end{tabular}

a. Dependent Variable: Number of places

b. Predictors in the Model: (Constant), GDP/inhabitant euro

c. Predictors in the Model: (Constant), GDP/inhabitant euro, Surface

\section{Conclusion}

All in all, Romania still has a long way to go before reaching its true potential in the area of rural tourism. This is reflected in the, not necessarily significant contribution of the entire tourism sector to Romanian GDP which was around 1.4\% in 2018, which is still below the global average level of $3 \%$ and the fact that a large proportion of tourists still prefer urban areas (approximately 70\% of incoming tourists), according to our investigation. In spite of these setbacks, the most recent statistics show a growth in the number of agritourist guesthouses and an increase in the number of guests and the number of nights spent in Romania, which is a sign that the rural tourism sector is moving towards the achievement of its true potential. Rural tourism is defined as all rural tourism activities, primarily agrotourism boarding houses and farms, but also small restaurants and hotels or other accommodation. However, there are countries that classify any activity undertaken outside the city as rural tourism. Research in the field of rural tourism development favors the creation of so-called integrated rural tourism (at both the theoretical and practical level) for the exploitation of underdeveloped regions, creating strong links between the social, cultural, economic and environmental resources. Our main findings were related to the number of structures in rural areas which were investigated by means stepwise linear regression. The results revealed that the best predictors are the surface area of the county and the GDP per capita at the level of the county. 


\section{Acknowledgement:}

The present paper has been financially supported by The Bucharest University of Economic Studies (ASE) „Dezvoltarea abilitaţilor antreprenoriale pentru doctoranzi si postdoctoranzi în domeniul stiinţelor economice" POCU/380/6/13/125015.

\section{References}

Anghelache, C., Anghel, M.G., \& Samson, T. (2018). Perspectiva evolutiei turismului in anul 2018. Revista Romana de Statistica, 5, 179-187.

Avram, D. (2017). Trends of tourist demand in Romania. Positioning of rural tourism among the tourist preferences. Cactus Tourism Journal, 15(1), 14-25.

Doncean, Gh. (2009). The algorithm for assessing the quality index of tourism products and services, In: Turismul Rural Românesc în contextul dezvoltării durabile, Actualitate şi Perspectivă, Talaba, I, Stanciu, M., Ungureanu, D., Haller, A.P. (coord.), Iasi: Tehnopress.

Dorobantu, M.R., Gheorghe, G., Nistoreanu, P. (2012). New Ways to Value Tourism Resources From Rural Environment. Competitiveness of Agro-Food and Environmental Economy, 1(2012), 385-390.

Gabriel, P. I. (2013). The impact of the economic crisis on tourism services-Case study Romania. Cactus Tourism Journal, 8(2), 20-31.

Ildiko, I., Radulescu, C.V., \& Florina, B. (2014). Romanian rural tourism: status and prospects by innovative organizational approaches. Revista de turism-studii si cercetari in turism, (17), 15-21.

Kantar, S., \& Svržnjak, K. (2017). Development of sustainable rural tourism. The Canadal European Journal of Regional Development and Tourism, 9(1), 26-34.

Kastenholz, E., Carneiro, M. J., Marques, C. P., \& Loureiro, S. M. C. (2018). The dimensions of rural tourism experience: impacts on arousal, memory, and satisfaction. Journal of Travel \& Tourism Marketing, 35(2), 189-201.

Matei, C. (2018). "Agroturismul zilelor noastre". Retrieved April 26, 2019 from: www.trendshrb.ro/business/agroturismul-zilelor-noastre/.

Perales, R. M. Y. (2002). Rural tourism in Spain. Annals of tourism Research, 29(4), 11011110.

Roberts, L., Hall, D., \& Morag, M. (2017). New directions in rural tourism. Routledge.

Roman, A. (2009). Satul turistic şi importanţa acestuia în localizarea produsului turistic rural. Revista/Journal Economica, 1(65), 85-88.

Saxena, G., Clark, G., Oliver, T., \& Ilbery, B. (2007). Conceptualizing integrated rural tourism. Tourism Geographies, 9(4), 347-370.

Stoican, M., \& Camarda, A. (2018). The Romanian rural tourism. Actuality and perspectives in the context of innovation economy. Social Economic Debates, 7(2), $1-9$.

Sumantra, I. K., \& Yuesti, A. (2018). Evaluation of Salak Sibetan Agrotourism to Support Community-Based Tourism Using Logic Model. International Journal of Contemporary Research and Review, 9(01).

"Turismul romanesc, $1.4 \%$ pondere in PIB, o tremie fata de media europeana". Retrieved April 26, 2019 from: www.businesscover.ro/turismul-romanesc-14-pondere-inpib-o-treime-fata-de-media-europeana/. 